\title{
O golpe de Estado, a burocracia e a teoria marxista do Estado
}

Coup d'État, bureaucracy and the Marxist theory of the state

\section{Pedro Felipe Narciso*}

\author{
https://doi.org/10.4322/principios.2675-6609.2022.163.012
}

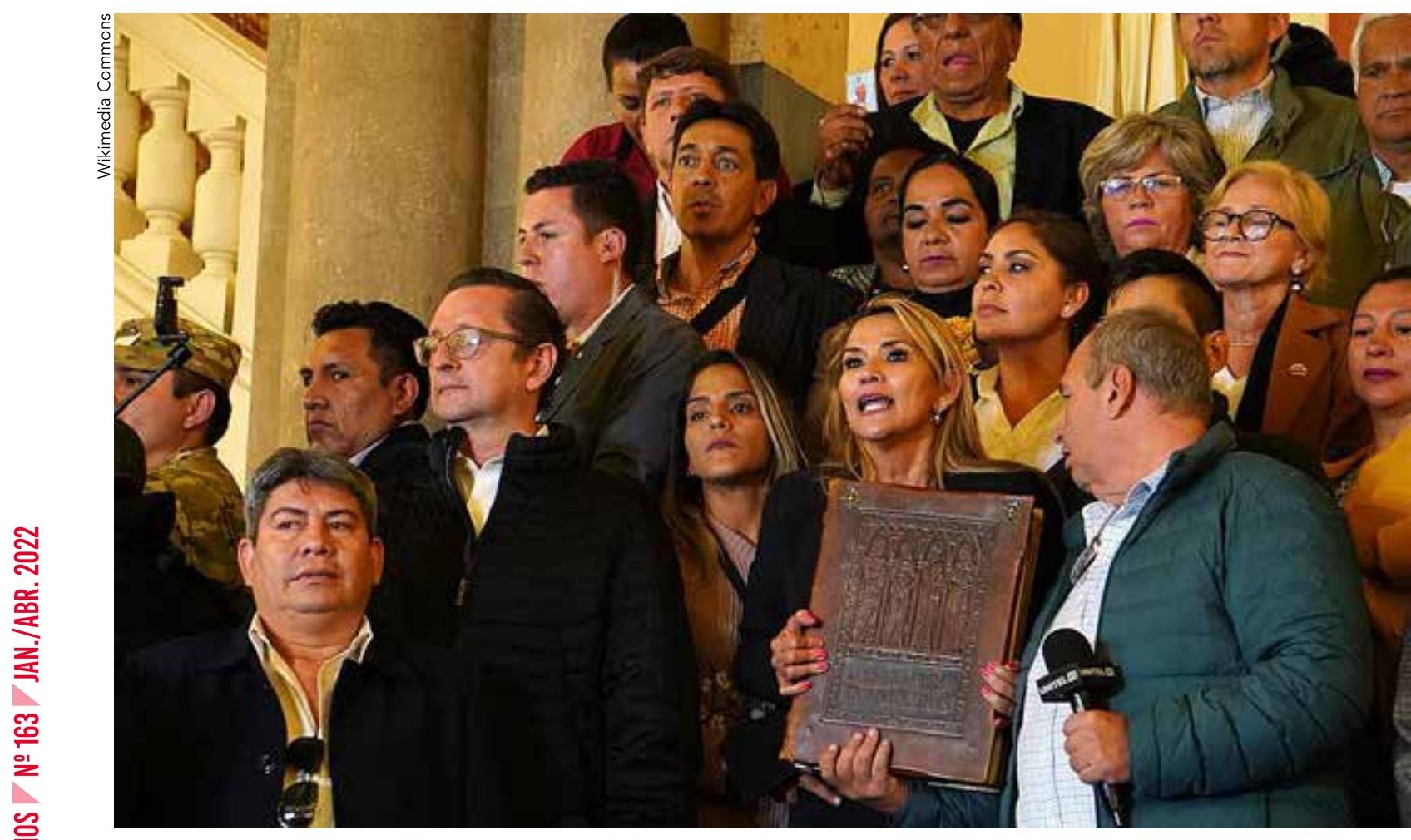

Cercada de parlamentares golpistas e segurando uma Bíblia, senadora Jeanine Áñez se autoproclama presidente da Bolívia após renúncia forçada de Evo Morales. Novembro de 2019 


\section{RESUMO}

O termo golpe de Estado é uma expressão de uso corrente entre os analistas marxistas para caracterizar determinados fenômenos. Apesar de amplamente utilizado, o termo, no entanto, não tem ainda uma definição rigorosa e consensual na teoria marxista. Nesse sentido, tendo como objeto o conceito de golpe de Estado, tem-se como objetivo argumentar em favor de uma definição restrita de golpe de Estado que seja coerente com a teoria marxista do Estado burguês. O tratamento teórico proposto para o conceito de golpe é o de tomá-lo como uma prática política de tipo particular na qual a burocracia participa do processo de usurpação do exercício de poder político de um ou mais ramos do aparelho de Estado. A principal implicação dessa definição é atestar o golpe de tipo parlamentar como um contrassenso teórico, pois tal concepção não observaria a hierarquia estrutural entre a representação burocrática e a representação política no aparelho de Estado burguês. Além dessa consequência principal, esboçam-se ao final do ensaio algumas possibilidades analíticas oferecidas pelo conceito de golpe como prática política de tipo particular.

Palavras-chave: Golpe de Estado. Marxismo. Burocracia. Golpe parlamentar. Prática política.

\section{ABSTRACT}

The term coup d'État is an expression commonly used by Marxist analysts to characterize a sort of phenomena. Despite being widely used, the term, however, still does not have a rigorous and consensual definition within the Marxist theory. In this sense, the aim of this article is to argue in favor of a restricted definition of a coup d'Etat which in our view is coherent with a Marxist theory of the bourgeois state. The theoretical treatment proposed is to take the concept of coup d'État as a political practice of a particular type in which the bureaucracy participates in the usurpation of political power in one or more branches of the state apparatus. This definition's main implication is to attest the parliamentary coup as a theoretical contradiction, as it would not observe the structural hierarchy between bureaucratic representation and political representation within the bourgeois state apparatus. In addition to this main consequence, some analytical possibilities offered by the concept of coup as a political practice of a particular type are outlined at the end of the essay.

Keywords: Coup d'État. Marxism. Bureaucracy. Parliamentary coup. Political practice. 


\section{INTRODUCC̣̃O}

O conceito de golpe de Estado tem larga tradição na filosofia e na ciência política, tendo o seu registro inaugurado na literatura ainda no século XVII. O referido conceito passou por uma série de transformações que acompanharam o surgimento do Estado burguês e sua correspondente teorização. A plasticidade das diferentes definições tem respondido à dinâmica horizontal do tempo, mas também à dinâmica vertical do debate teórico. Esta última ganhou um novo impulso, o qual se deve muito à recente onda de destituições presidenciais ocorridas na América Latina ${ }^{\mathrm{I}}$ e que, ameaçando a continuidade dos já estreitos regimes democráticos da região, resgatou o conceito de golpe de Estado como uma prioridade para a pesquisa sobre as conjunturas políticas no subcontinente.

Dito isso, tem-se como objeto do presente ensaio o conceito de golpe de Estado. Aqui, o objetivo é oferecer uma definição do conceito de golpe de Estado adequada à teoria marxista do Estado burguês, mais especificamente à teoria da organização do aparelho desse tipo de Estado. A ideia-força que conduz o conjunto da argumentação é a de que o golpe de Estado é um fenômeno cuja ocorrência depende, essencialmente, da participação da burocracia de Estado. Desse modo, caracterizar um golpe de Estado como golpe parlamentar configuraria um contrassenso teórico, pois tal caracterização não observaria a hierarquia estrutural entre os ramos do aparelho de Estado burguês, tal como corretamente designado pela teoria marxista.

No sentido de integrar de modo coerente o conceito de golpe de Estado à teoria marxista da organização do aparelho de Estado burguês, propõe-se que o golpe de Estado é um tipo particular de prática política. Assim, sobre esse conceito devem incidir as determinações mais abstratas que especificam a prática política em geral e as determinações que especificam o golpe de Estado como prática política de tipo particular. Considerando os elementos que compõem esse tipo particular de prática política, deve ser possível também observar as combinações que especificam as diferentes modalidades de golpe de Estado.

Com o intuito de sustentar e desenvolver as concepções logo acima enunciadas, este ensaio tem o seu desenvolvimento composto por três seções, além desta introdução e das considerações finais. Na seção seguinte, apresenta-se a teoria marxista do Estado burguês, nessa o objetivo é estabelecer um parâmetro teórico pelo qual a coerência da argumentação deve ser balizada. Na terceira seção, tomam-se como objeto de ilustração teórica as análises de autores que caracterizam o golpe de 2016 como golpe parlamentar. Na referida seção, o objetivo é indicar o reconhecimento da participação burocrática como uma constante nas análises dos autores que ocultam essa participação enunciando o "golpe parlamentar". Por fim, na quarta seção, o objetivo é fundamentar uma definição do conceito de golpe de Estado em acordo com a teoria-parâmetro da seção segunda, conjecturando, de modo subsidiário e provisório, combinações que especificam algumas das modalidades possíveis de golpe.

1 Citam-se especialmente os bem-sucedidos golpes de Estado no Haiti, em 2004; em Honduras, em 2009; no Paraguai, em 2012; no Brasil, em 2016; e na Bolívia, em 2019. 


\section{O golpe de Estado é um fenômeno cuja} ocorrência depende, essencialmente, da participação da burocracia de Estado. Desse modo, caracterizar um golpe de Estado como golpe parlamentar configuraria um contrassenso teórico, pois tal caracterização não observaria a hierarquia estrutural entre os ramos do aparelho de Estado burguês

\section{A TEORIA MARXISTA DO ESTADO BURGUÊS}

Nesta seção apresenta-se de maneira sumária a teoria marxista do Estado burguês. Vale salientar que não constitui um objetivo sustentar a validade dessa teoria em relação às alternativas existentes, pois neste texto a teoria marxista do Estado é ao mesmo tempo um a priori teórico, um objeto e um resultado. Ou seja, trabalha-se com os pressupostos da teoria marxista do Estado sobre um conceito específico dessa mesma teoria para retificá-lo de modo a tornar a própria teoria mais consistente.

Quando se enuncia a teoria marxista do Estado burguês, faz-se referência a uma combinação específica de quatro determinações, as quais definem as fronteiras de um determinado objeto, diferenciando-o de uma massa confusa e indefinível. A primeira dessas determinações refere-se a "um conjunto de conceitos e de teses" (BOITO JR., 202Ia), isto é, a teoria. A segunda refere-se a um conjunto particular de conceitos e teses, a teoria marxista. A terceira determinação, o Estado, oferece três coordenadas complementares: a) a menção ao Estado como objeto indica o hemisfério da ciência da história, o materialismo histórico, e não o hemisfério da ciência das práticas teóricas, o materialismo dialético; b) com os pés sobre o continente do materialismo histórico, o conceito fundamental observado é o de modo de produção, ou seja, a unidade correspondente entre os tipos de estrutura econômica e os tipos de estrutura política, e, por fim, c) trata-se, assim, das estruturas políticas típicas dos modos de produção em que as estruturas econômicas estão cindidas entre uma classe explorada e uma classe exploradora, o Estado. A quarta e última determinação distingue, dentre os diversos modos de produção classistas, um deles, o modo de produção capitalista, que, tendo uma estrutura econômica classista específica, tem também uma estrutura política classista de tipo particular, o Estado burguês. 
Partindo da terceira determinação - já no território da teoria marxista percebe-se que as estruturas políticas não são mônadas absolutas autoengendradas. Aquelas se relacionam com as estruturas econômicas, e em conjunto com estas constituem um conceito mais geral, o modo de produção. Nos modos de produção cindidos em classes, a estrutura política típica e necessária efetiva-se como Estado, que é definido como um conjunto mais ou menos especializado e unificado de organizações que têm por função principal garantir a dominação de uma classe. Essa definição simples e abrangente caracteriza o fenômeno Estado como um todo. Em todo e qualquer modo de produção, o Estado se refere a um corpo de funcionários especializados em garantir a dominação de uma classe (SAES, I982; 1987). Tais funcionários realizarão essa função pelo emprego de duas atividades sempre necessárias e nunca suficientes: a possibilidade efetiva do uso da violência e a imposição de tributos. Portanto, todo e qualquer Estado é constituído por funcionários capazes de exercer a violência (forças armadas) e capturar excedentes por meio de impostos (forças coletoras) (LAZAGNA, 20I7). Quando esses funcionários monopolizam as atividades de gestão do aparelho de Estado, observa-se a forma de Estado ditatorial. Quando a classe dominante tem no aparelho de Estado um órgão efetivo de representação, compartilhando a administração do Estado com os funcionários, observa-se a forma de Estado democrática (SAES, 1987).

Se a função do Estado é garantir a dominação de classe, é fundamental salientar que em cada modo de produção domina uma classe específica, que, mantendo relações de produção específicas, torna necessário que a dominação se efetive também de modo específico e correspondente. A esse modo particular de organização do Estado para organizar a dominação de cada classe em cada modo de produção, chama-se tipo de Estado (SAES, 1987).

O tipo de Estado que corresponde à dominação da classe capitalista e que, portanto, é capaz de garantir a reprodução da dominância do modo de produção capitalista é o Estado de tipo burguês. Esse tipo de Estado, assim como os demais, caracteriza-se, primariamente, pela sua estrutura, que, nesse caso, reúne dois sistemas de valores fundamentais: a) o direito igualitário; e b) o burocratismo (SAES, I982; 1987).

O direito igualitário é a face da estrutura jurídico-política do Estado burguês que regula e garante a existência das relações de produção capitalistas na medida em que trata os proprietários e os não proprietários de capital como sujeitos abstratos e equivalentes, ambos supostamente portadores de mesma autonomia. Esse tratamento jurídico em que a igualdade formal das vontades é inviolável garante a existência das relações de compra e venda de força de trabalho típicas do capitalismo na medida em que: contém a voracidade cega dos exploradores individuais, o que poderia acabar por restaurar as relações de produção em que o trabalhador livre, explorado por contrato, voltasse à condição de servo ou escravo, e debilita a tendência à auto-organização operária e a possível superação das relações de produção vigentes, pois, quando um trabalhador vende a sua força de trabalho para um capitalista, o direito 


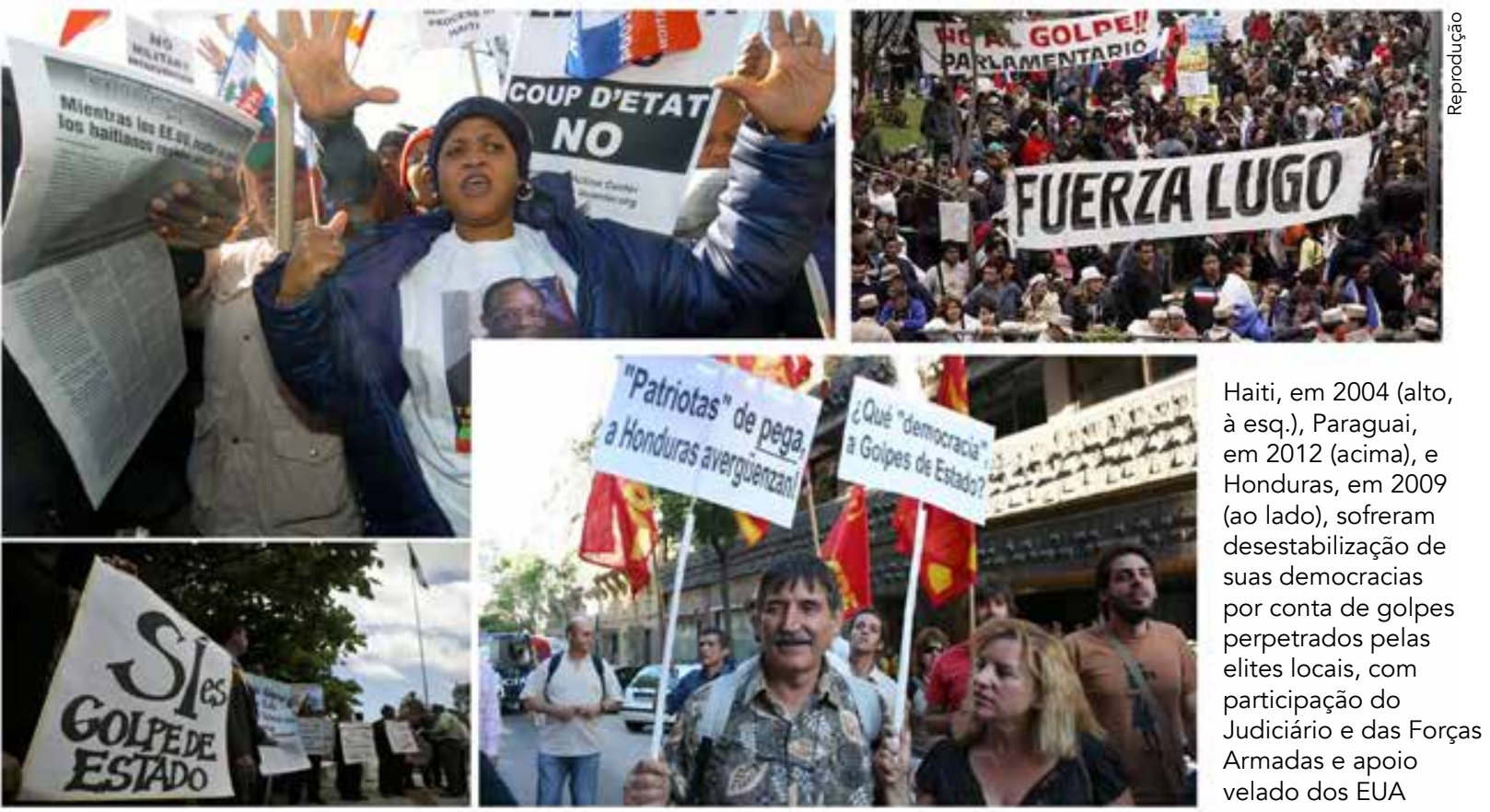

não reconhece essa relação como relação desigual de exploração entre coletividades distintas, mas como um contrato entre dois sujeitos individuais equivalentes, livres e autônomos. Dessa forma, as relações de produção entre classes antagônicas são sentidas como relações entre indivíduos iguais. A essa sensação - que as classes trabalhadoras sentem como competição individual no mercado de trabalho, e os burgueses, como competição entre os capitais individuais - chama-se efeito de isolamento.

O segundo elemento da estrutura jurídico-política que se efetiva no Estado burguês é o burocratismo. Este constitui um conjunto de princípios que organizam e regulam o próprio Estado, ou seja, que constrange os funcionários do Estado a agir em acordo com a reprodução do modo de produção capitalista. As duas características fundamentais do burocratismo são: a) as tarefas do Estado não são monopolizadas pela classe exploradora; assim, estão formalmente habilitados a participar do aparelho de Estado os membros individuais de todas as classes sociais; e b) sendo juridicamente possível qualquer um ser funcionário do Estado, a seleção é feita mediante o critério formal e expresso do mérito individual, atestado de modo geral e impessoal. A impessoalidade e universalidade do Estado diante dos membros individuais de todas as classes inviabiliza, mais uma vez, que uma fração da classe dominante instrumentalize o Estado contra a classe explorada e acabe por restaurar a extorsão de excedente por meio de coerção direta, o que é incompatível com a reprodução do modo de produção capitalista. Dessa mesma impessoalidade e universalidade deriva a sensação de que o Estado representa igualmente os interesses de todas as classes e que, portanto, não constitui uma instituição especializada em exercer a dominação política, mas especializada em realizar o interesse geral do povo-nação, o bem comum. Dessa maneira, a classe operária tem neutralizada a tendência à auto-orga- 
nização classista, orientando suas demandas pontuais para o Estado, que as atende na medida em que tais demandas garantam a reprodução da sua condição de classe explorada e dominada. Tal sensação, a de que o Estado é representante geral e que seus funcionários são representantes do povo-nação, é chamada de efeito de representação da unidade.

O direito e o burocratismo são duas peças indissociáveis da estrutura jurídico-política do Estado de tipo burguês. A estrutura, como já enunciado, constitui um sistema de valores prescritivos indispensáveis à reprodução de um modo de produção. Sendo um sistema de valores, não tem por si uma existência material, realizando-se sempre por meio de um aparelho que se orienta por ela. Eis o aparelho de Estado, um "conjunto de recursos materiais e humanos" (SAES, 20I2, p. 284) forçosamente organizados de determinado modo, cumprindo a função de garantir a dominação de uma classe.

A enunciação do direito igualitário, necessário às relações de compra e venda da força de trabalho, implica um reconhecimento dessa igualdade para a participação nos postos dos diferentes ramos do aparelho de Estado, o que atribui ao Estado burguês - Estado de classe como qualquer outro - uma aparência pública, de Estado de todos. De tal modo, quando a classe dominante demanda uma forma de Estado democrática - ou seja, a presença de uma assembleia eleita que compartilha a gestão da dominação com o pessoal de Estado - , a monopolização dessa assembleia pelos membros das classes dominantes acaba por desautorizar o burocratismo, em primeiro lugar, e o direito, em segundo, neutralizando os efeitos de isolamento e de representação da unidade que garantem a reprodução do modo de produção. Dessa maneira, o direito civil igualitário, necessário às operações de compra e venda e à participação nas carreiras de Estado (representação burocrática), tende a engendrar um direito político igualitário, abrindo aos membros individuais de todas as classes também a participação no ramo de representantes eleitos (representação política) (SAES, I982).

Vale ainda salientar que o burocratismo, também respaldado pelo direito igualitário e seu efeito individualizador, não se relaciona com os funcionários de Estado como membros de suas respectivas classes. No Estado, o representante burocrático ali instalado aparece como um cidadão que representa o povo-nação por meio dos valores burocráticos cristalizados no aparelho de Estado. Caso esse ou aquele representante burocrático vacile no cumprimento das funções atribuídas a sua posição, o representante sofrerá sanções, pois não é dono da posição, mas um funcionário com obrigações.

No caso da representação política, o grau de autonomia do representante diante do aparelho de Estado parece maior, pois, sendo eleito por uma parcela específica dos chamados "cidadãos", eventualmente o eleito pode estar representando uma classe trabalhadora votante e organizada que tem por estratégia utilizar o parlamento como instrumento para a realização do programa político da classe operária. 
Supondo que as representações políticas da classe operária constituam uma vanguarda decidida, competente e que consiga driblar os diversos filtros e tentativas de cooptação próprias à representação política, e que a própria base da classe operária esteja fortemente organizada, com uma consciência clara acerca dos efeitos ideológicos da estrutura do Estado burguês, ainda assim a representação política antagonizaria com a representação burocrática, o núcleo insuperável dos funcionários profissionais não eleitos responsáveis pela administração da dominação. Nesse sentido, torna-se imprescindível a seguinte avaliação de Décio Saes sobre a relação entre os dois tipos de representação popular no seio Estado burguês.

A organização, numa formação social, de alguma forma de representação política liberal, corporativa ou plebiscitária — não produz, entretanto, a desagregação do burocratismo; ela determina, antes, o desenvolvimento, no seio do Estado burguês, de uma contradição entre as duas formas de representação popular, a política e a burocrática. Essa contradição foi detectada - de modo desigual e em nível de profundidade variável, é claro - por todos os analistas do Estado burguês: exemplificando apenas com autores clássicos, por Hegel (contradição entre burocracia e corporações), por Marx (contradição entre burocracia e parlamento) ou por Weber (contradição entre burocratização do Estado e democracia política). Ela se manifesta, concretamente, como contradição entre os agentes do burocratismo (funcionários) e os representantes políticos (membros de um parlamento democrático, de uma Assembleia corporativa ou de uma liderança plebiscitada). Tal contradição pode se prolongar no tempo, ou se resolver através da liquidação da representação política pelo burocratismo (o contrário é impossível, já que o burocratismo é a própria estrutura do Estado burguês). Mas um ou outro desenvolvimento da contradição depende, fundamentalmente, do próprio desenvolvimento da luta de classes na formação social em questão (SAES, 1982, p. 36).

Os ramos da representação burocrática do aparelho de Estado, ou seja, o corpo dos funcionários de carreira organizados sob os princípios do burocratismo, são, de fato, a realização da estrutura jurídico-política do Estado burguês. Esses são os responsáveis por regular o conjunto das atividades estatais e não estatais por meio da possibilidade do uso da violência organizada e sistemática. O núcleo duro do burocratismo tem no seu centro a burocracia militar, os profissionais dessa violência organizada e sistemática; as forças coletoras, responsáveis pela extorsão e administração do excedente econômico necessário à reprodução do aparelho de Estado, e, ainda, o Judiciário, a representação burocrática que, sendo o direito encarnado, cumpre a função expressa de observar e aplicar o direito igualitário e o próprio burocratismo, regulando as relações dos agentes da produção entre si, dos ramos do aparelho de Estado entre si e também as relações entre os agentes da produção e o aparelho do Estado.

A representação política no Estado, por seu turno, é composta pelo conjunto de representantes eleitos pelo voto popular e com mandatos determinados. Tomando o exemplo do Brasil, podemos citar vereadores, prefeitos, deputados, senadores, vi- 
ce-presidentes e presidentes. Além, é claro, dos ministros e secretários cujo mandato depende dos chefes de governo.

O Estado foi até aqui apresentado de forma cristalina, pois indicamos características descobertas após décadas de pesquisa e elaboração teórica levadas a cabo por um sem-número de autores. No entanto, o Estado não constitui uma realidade simples e transparente cuja existência é autoevidente. Além de valores prescritivos indispensáveis (a estrutura) e de recursos materiais e humanos orientados pela estrutura (o aparelho), o Estado é também uma instituição (SAES, 20I2), que é definida como um conjunto declarado de regras, princípios, ritos e convenções. Portanto, referir-se à instituição é referir-se à superfície oficial do Estado, ao modo como o aparelho de Estado se enxerga e se apresenta. Esse conjunto de regras, princípios etc. parece conduzir de modo inexorável toda a atividade estatal. No entanto, o institucional não é rigorosamente observado em seu conjunto: tais princípios, regras e convenções são considerados apenas parcialmente, engajando, legitimando e acobertando os meios e os objetivos fundamentais da atividade estatal.

Por fim, tem-se, então, o seguinte cenário: a) o Estado é ao mesmo tempo uma estrutura, um aparelho e uma instituição; b) o ramo da representação burocrática realiza por si mesmo a estrutura jurídico-política do Estado burguês; c) quando a representação burocrática coincide com a representação política, tem-se o Estado de tipo burguês sob a forma de ditadura; d) quando a representação política não coincide com a representação burocrática e esta compartilha a administração do Estado com um órgão efetivo de representantes eleitos, tem-se o Estado de tipo burguês sob a forma democrática; e) em caso de conflito entre os dois tipos de representação popular, a representação burocrática sempre triunfará sobre a representação política; caso contrário é o próprio aparelho do Estado burguês que se dissolve.

\section{A BUROCRACIA NA HIPÓTESE DO GOLPE PARLAMENTAR}

Nesta terceira seção do ensaio tomam-se como objeto de observação crítica as análises que caracterizam o golpe de 2016 no Brasil como um golpe parlamentar. O objetivo principal aqui é o de demonstrar como os autores indicam a fundamental participação da representação burocrática no processo golpista, no caso, os órgãos judiciais do Judiciário e do Executivo, ao passo que ocultam essa participação na enunciação do conceito com o qual caracterizam o processo, o golpe parlamentar. A escolha do caso brasileiro como caso de ilustração justifica-se por dois argumentos: a) os autores compõem o debate teórico no qual este texto pretende se inserir, e b) o caso brasileiro é o mais conhecido em detalhes pelo público ao qual se destina o escrito, bem como por quem o escreve.

O primeiro autor elencado aqui é Renato Perissinotto, que define sinteticamente um golpe de Estado como o "rompimento das regras do jogo sucessório", "efetuado por órgãos do Estado" (PERISSINOTTO, 20I6, p. 2). A partir disso, Perissinotto distingue num golpe os seus "perpetradores intencionais" (no caso brasileiro, a 


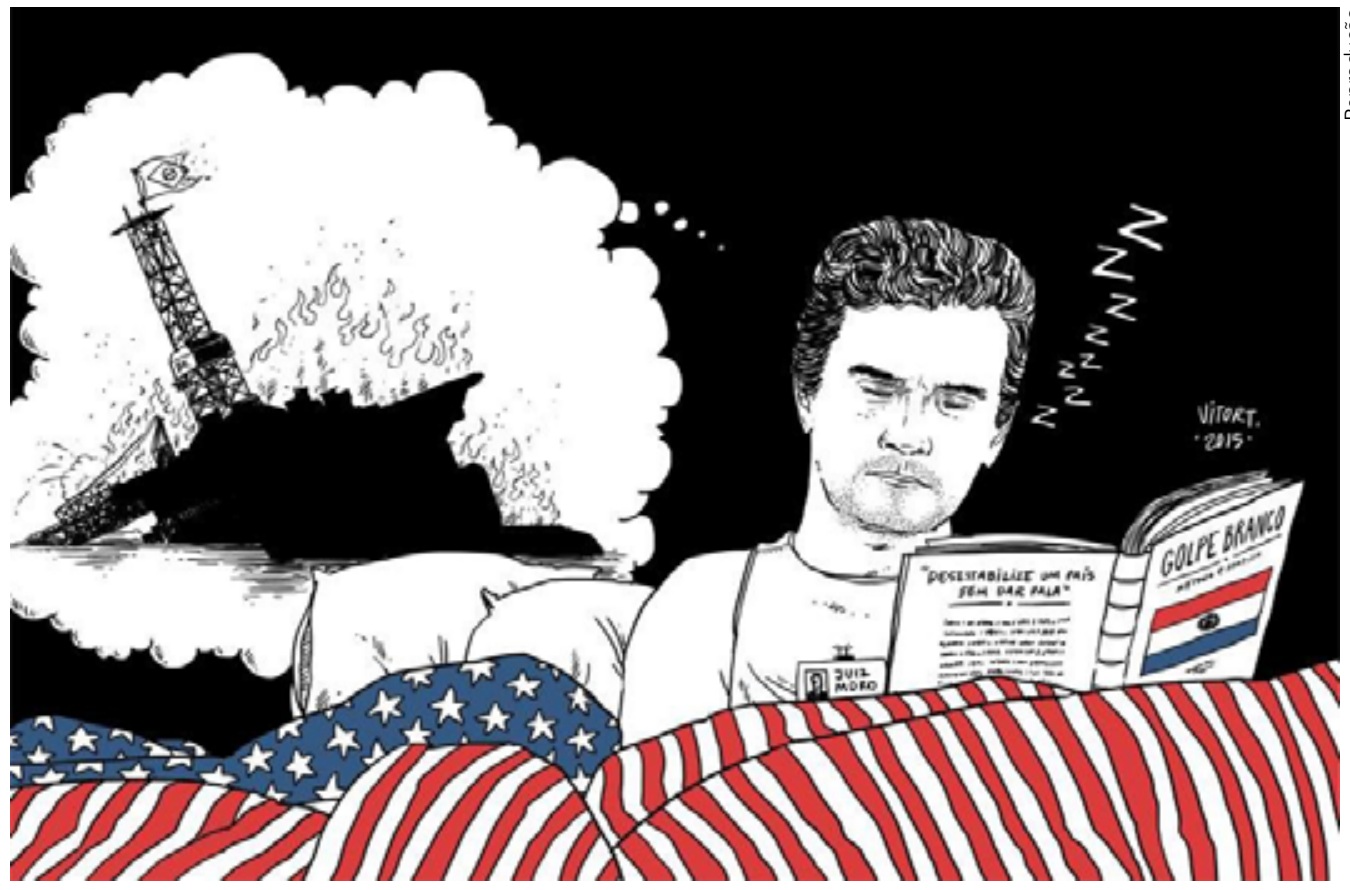

O então juiz Sergio Moro, em charge de Vitor Teixeira, 2015

coalizão política no parlamento) daqueles agentes que criam as suas condições (no caso brasileiro, a mídia, os protestos de rua, a operação Lava Jato, a Polícia Federal, o Ministério Público e o Judiciário). Negligenciando no conceito estes últimos agentes, Perissinotto toma como critério único na caracterização de um golpe os seus "perpetradores intencionais", definindo, assim, o golpe de 2016 como um golpe de tipo parlamentar.

A análise de Perissinotto traz uma contribuição importante ao distinguir duas funções políticas num golpe de Estado, a função das "forças perpetradoras" e a função daqueles agentes que "criaram as condições para o golpe". Reconhecendo essa distinção, o autor poderia progredir com a observação de alianças internas entre os diferentes ramos do aparelho de Estado, indicando suas configurações. No entanto, ao fazer sua caracterização sobre o processo golpista, o autor sonega a participação da burocracia e reconhece no seu conceito apenas a participação do parlamento, considerando assim aquele golpe como golpe parlamentar.

Jessé Souza também qualifica o golpe de 2016 como golpe parlamentar. O autor entende que, embora o Judiciário tenha tido um protagonismo inicial no processo golpista a partir de vazamentos seletivos e de perseguição a Lula, o sistema de Justiça não pôde deflagrar o golpe jurídico sob o risco de perder a "aura de imparcialidade", de tal modo que "entrou em cena o golpe parlamentar" (SOUZA, 20I6, p. I27).

A leitura de Souza pode trazer também um elemento importante para a análise daquele golpe, que é a sua forma. O golpe jurídico, puro e simples, poderia romper com a roupagem institucional do Estado, o seu conteúdo manifesto de neutralidade e imparcialidade política. A participação do parlamento e o cumprimento dos ritos 
institucionais, por seu turno, reafirmaram essa roupagem institucional, conferindo "legitimidade" ao processo. Jessé Souza, no entanto, não considera um importante elemento destacado no texto de Perissinotto, que é o fato de o impeachment ser "apenas um ponto numa narrativa muito mais ampla” (PERISSINOTTO, 20I6, p. 4). Por que seria correto considerar, então, só o ponto de chegada dessa narrativa (o impeachment) e não o conjunto do processo?

Um terceiro autor que merece ser destacado é André Singer, que não identifica o golpe parlamentar como modalidade de golpe de Estado, mas como um processo de natureza diferente. Para Singer, o golpe de Estado sempre envolve a ação das Forças Armadas, ao passo que o golpe parlamentar se processa conforme os preceitos constitucionais. A partir dessa conceituação, Singer, portanto, considera o golpe do impeachment como golpe parlamentar, pois a destituição presidencial ocorreu obedecendo a um critério previsto institucionalmente, o número mínimo de votos exigidos nas duas casas parlamentares (SINGER, 20I8).

Singer dá destaque ao cumprimento dos ritos institucionais para distinguir a natureza do golpe de Estado da natureza do golpe parlamentar. O autor, aqui, negligencia dois elementos. Primeiro, que o impeachment, assim como toda a cena política das democracias burguesas, é um processo regulado juridicamente, e segundo, que, embora as instituições proclamem o direito como congruente ${ }^{2}$ e completo ${ }^{3}$ (SAES, 2012), o discurso jurídico não é nem uma coisa nem outra, permitindo assim aos agentes do burocratismo uma ampla margem para manobrar as instituições sem romper com elas. É o que Perissinotto chamou de "uso casuístico das leis". Portanto, o trabalho de encontrar um caminho jurídico para o golpe não foi um trabalho exclusivamente parlamentar. O cumprimento dos ritos institucionais foi um trabalho colaborativo em que o Judiciário e demais forças judiciais, tensionando as instituições ao seu limite, construíram, com sua "aura de imparcialidade", um caminho institucional possível no qual o golpe acabasse por ser também um impeachment.

O último autor que aqui se destaca é Armando Boito Jr., cujas análises serão observadas de modo um pouco mais detalhado, pois o escopo teórico de Boito Jr. é também aquele que mobiliza os esforços e pretensões do autor deste ensaio. Armando Boito Jr. caracteriza o que ele mesmo chama de golpe do impeachment como um golpe parlamentar. Entretanto, nas análises do autor, o elemento judicial (representação burocrática) tem uma importância central. Em seu último livro, no qual o autor trata da crise política brasileira, Boito Jr. ressalta que

a oposição neoliberal pode agir à vontade na apuração da corrupção porque sabe
que o Judiciário, o Ministério Público e a Polícia Federal são rigorosos e até abusivos
na investigação da corrupção dos políticos do governo e das grandes empresas que
integram a burguesia interna e condescendentes e cúmplices com a corrupção dos
governos e dos partidos da oposição neoliberal. Os juízes, procuradores e delegados

2 O princípio da congruência assevera que o sistema jurídico é sempre lógico e harmonioso.

3 O princípio da completude assevera que o sistema jurídico é sempre completo, inteiro e pleno, podendo e devendo, assim, ser aplicado a toda e qualquer situação. 


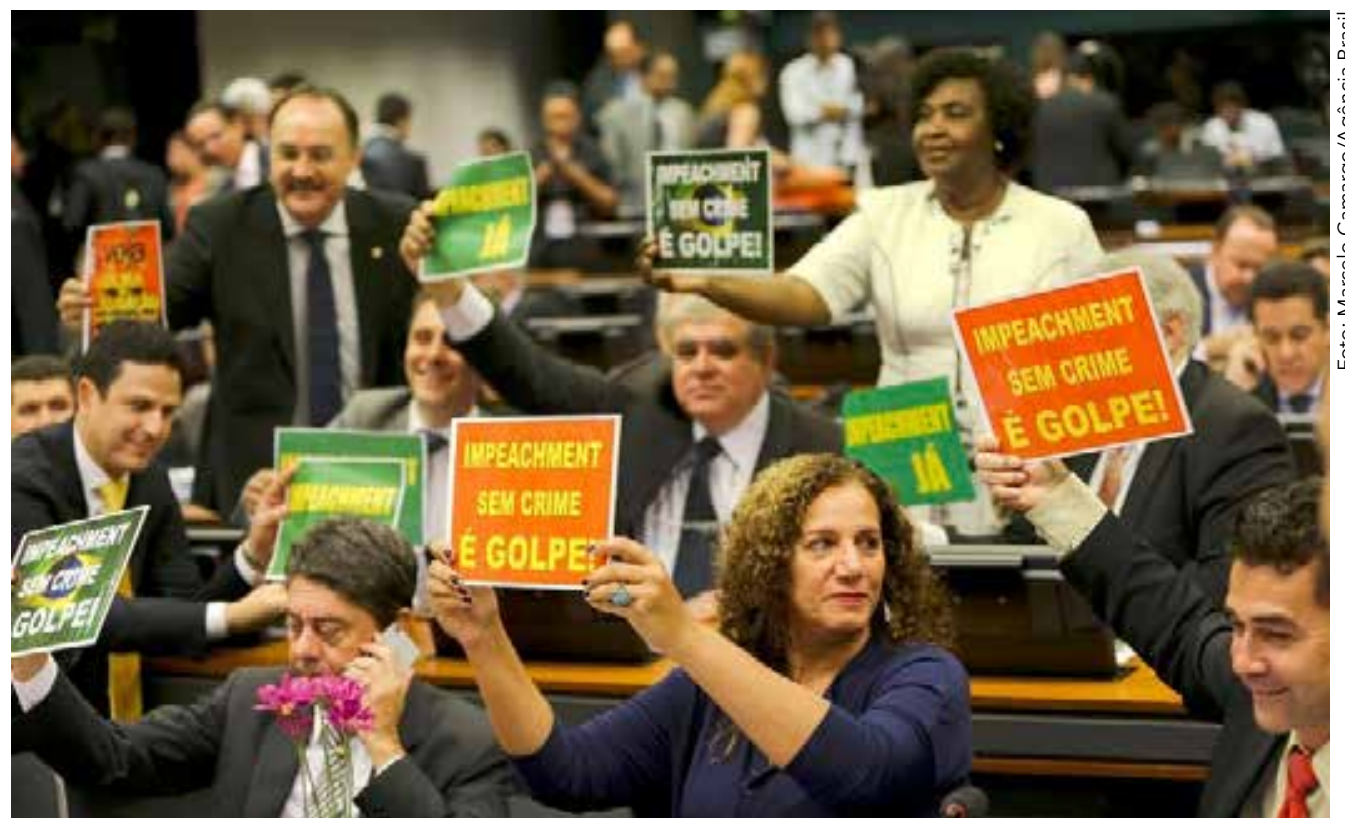

Parlamentares governistas protestam durante reunião de comissão especial no Congresso Nacional contra o andamento do processo de impeachment da então presidenta Dilma Rousseff. Brasília, abril de 2016

que controlam aquelas instituições do Estado pertencem, eles próprios, à alta classe média e estão engajados na luta contra os governos do PT (BOITO JR., 2020, p. 27).

Nessa citação, fica evidente que o autor considera o papel ativo e parcial do Judiciário, do MP e da PF na apuração dos crimes de corrupção, sendo todos esses agentes, como ele mesmo diz, "rigorosos e até abusivos" com alguns e "condescendentes e cúmplices" em relação a outros. É possível intuir então que esse padrão de operação dos órgãos judiciais não se restrinja às acusações de corrupção, abarcando também eventos outros, tais como crimes de responsabilidade, que foram a motivação manifesta e legitimadora do impeachment.

Em outra passagem o autor ressalta mais uma vez uma relação de colaboração e aliança entre os ramos da representação política e os ramos da representação burocrática. Segundo ele, o "principal inimigo a ser combatido é o golpe de Estado branco preparado pelo PSDB com o apoio das instituições estatais incumbidas de manter a ordem - Polícia Federal, Ministério Público, Judiciário" (BOITO JR., 2020, p.27). Deixando ainda mais clara a relação que esses agentes têm entre si, o autor especifica uma base de apoio do golpe e uma força dirigente:

Os setores politicamente ativos do Judiciário, do Ministério Público e da Polícia Federal representam de um modo muito peculiar, embora já verificado em outros momentos da história política do Brasil, a alta classe média, que foi a base de apoio do golpe de Estado que depôs Dilma Rousseff; o Executivo Federal e as forças majoritárias no Legislativo representam a fração da burguesia que foi a força dirigente desse golpe de Estado [...]. Juízes, procuradores e delegados são, ao mesmo tempo, burocratas do ramo repressivo do aparelho de Estado e integrantes da fração superior da alta classe média (BOITO JR., 2020, p. 57, 59). 
Boito Jr. entende que a Lava Jato operou como "instrumento político para a burguesia associada” (BOITO JR., 2020, p. 78) e que a relação entre a operação e os interesses dessa fração burguesa é negligenciada pelos analistas que tomam o processo político como uma dimensão social cristalina e evidente. Como advertência teórico-metodológica aos observadores da cena política, Boito Jr. ressalta que "parte muito importante do processo decisório tem lugar nos corredores e gabinetes da burocracia de Estado, longe dos olhos do público" (BOITO JR., 2020, p. 7I).

Além de toda a análise do processo político brasileiro oferecida por Armando Boito Jr., considerada aqui como a mais rigorosa, o autor oferece também algumas contribuições pontuais que merecem destaque. A primeira é a combinação dos termos para nomear o fenômeno de 20I6, que, ao mesmo tempo que é golpe, é também impeachment, portanto, considera-se aqui que golpe do impeachment é a nomenclatura mais adequada para designar aquele acontecimento. $O$ segundo ponto trata do estabelecimento de alianças e funções entre os ramos do aparelho de Estado. E o terceiro refere-se à advertência teórico-metodológica destacada, que concebe a cena política como uma superfície opaca que oculta não só as práticas políticas das classes dominantes como também as práticas políticas da burocracia de Estado, proclamadas pelas instituições como práticas de caráter puramente técnico.

Estabelecendo a análise de Boito Jr. como a mais acurada referência para a observação daquele processo, qual seria, então, o ponto de discordância? Justamente a caracterização do golpe do impeachment como golpe puramente parlamentar. Se nas considerações do autor é possível observar uma série de indicações sobre a participação fundamental das forças judiciais do início ao fim do processo, por que então se desconsideraria essa participação dos agentes do burocratismo tomando somente os eventos autoproclamados da cena política parlamentar para caracterizar o golpe?

Até aqui se observou que os autores que advogam a caracterização de golpe parlamentar - Perissinotto, Souza, Singer e Boito Jr. - arrolam diversos momentos em que a presença do aparato judicial foi decisiva, reconhecendo tal importância num ou noutro momento do golpe do impeachment. No entanto, chegado o momento de tipificar o golpe, o acúmulo da análise sobre o aparato judicial é sonegado, tornando teoricamente praticável a evocação do conceito de golpe parlamentar puro e simples.

Essa defasagem entre a análise empírica e a caracterização teórica do fenômeno dá-se, de acordo com o que se defende neste texto, por dois motivos principais. Primeiro, pela desconsideração da premissa teórica que assevera a existência de uma hierarquia estrutural entre os ramos do aparelho de Estado burguês, como se o parlamento (isoladamente), ramo da representação política, tivesse condições de alterar hierarquias institucionais por meio de práticas institucionalmente duvidosas ou imprevistas, atropelando, assim, o direito e a burocracia sem sofrer, com isso, maiores constrangimentos. O segundo motivo é a desconsideração do caráter opaco da cena política, não levando em consideração a importância das movimentações mais ou menos silenciosas da burocracia para o desfecho dos processos que aparecem na cena política como sendo límpidos e autônomos. 


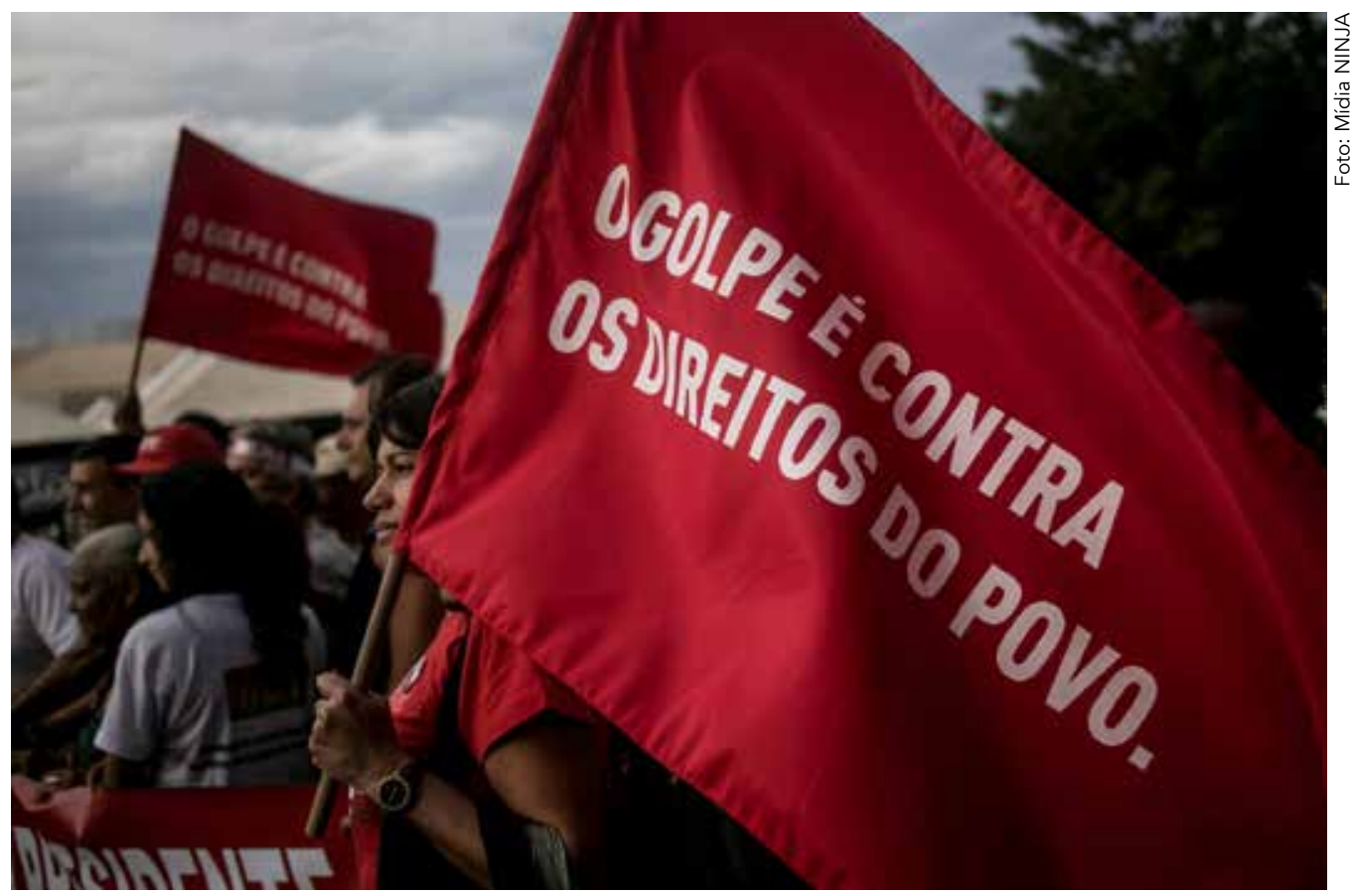

\section{O GOLPE DE ESTADO COMO PRÁTICA POLÍTICA TÍPICA DA BUROCRACIA}

O objetivo principal nesta seção é propor uma definição fundamentada do conceito de golpe de Estado que seja coerente com a teoria marxista do Estado burguês. Feito isso, pretende-se apresentar, de modo subsidiário, algumas das combinações possíveis entre os elementos que compõem a definição proposta e ilustram a operacionalidade do conceito. Antes disso, no entanto, cabe expor aqui algumas recomendações gerais de ordem epistemológica pelas quais esse trabalho de ajuste conceitual está orientado.

O termo conceito é definido pelo dicionário Michaelis (CONCEITO, 202I) como uma "representação mental das características gerais de um objeto". Trata-se de uma definição razoável e autocoerente da qual é possível desdobrar questões teóricas pertinentes, tais como o papel da linguagem no processo de representação ou, então, a definição do termo objeto e suas possíveis variáveis qualitativas. Dentre essas diversas questões, para os fins deste trabalho, considera-se importante frisar o conteúdo da expressão características gerais, ou seja, a propriedade indispensável dos conceitos de designar assertivamente as características invariantes que delimitam as fronteiras de identidade de um objeto ${ }^{4}$.

Um conceito, portanto, indica determinações invariáveis próprias a um tipo de objeto. As determinações devem ser invariáveis, pois sem tais determinações não haveria autorização lógica para definir o objeto como tal, sob pena de se sacrificar a

4 Considera-se legítimo o procedimento de tomar representações "caóticas" e pré-elaboradas da linguagem corrente como matéria-prima do trabalho teórico, que nem sempre precisa empregar os conceitos teóricos previamente trabalhados. Frisa-se ainda, aqui, o formato de ensaio do presente texto, cuja pretensão passa longe de uma revisão de literatura sobre a definição desse ou de qualquer outro conceito. 
lógica do conhecimento ao desígnio do enunciado arbitrário. Armando Boito Jr. chama a atenção para esse problema ao distinguir dois tipos de definições sobre o conceito de fascismo, as definições "teóricas e sintéticas" e as "definições descritivas". Estas últimas tendem a arrolar uma série de elementos presentes em um ou mais exemplos históricos do que consideram fascismo, sem demonstrar, no entanto, os critérios que justificam: a) a seleção de alguns elementos e a exclusão de outros; e b) a seleção de experiências históricas como exemplos de um conceito que, em tese, ainda não existe e será formulado a partir delas (BOITO JR., 202Ib). Trata-se, portanto, de duas arbitrariedades, a seleção dos casos e a seleção de seus elementos típicos.

As definições teóricas e sintéticas fogem do arbítrio referido, pois, além de expressar "informações empíricas" sobre os fenômenos, expressam também o conhecimento teórico previamente disponível, servindo, assim, como um guia da investigação. Tais definições são capazes de indicar o tipo de fenômeno para o qual se mira, indicando também as categorias invariantes que neste devem ser destacadas e desenvolvidas. Um conceito teórico e sintético, que não tem a pretensão de esgotar a complexidade de um fenômeno, deve atender, portanto, a um critério de duas coerências. A primeira coerência é interna (SAES, 200I) e refere-se à integração logicamente não contraditória do conceito com o seu respectivo sistema teórico. A segunda coerência é externa (SAES, 200I) e refere-se à capacidade do conceito de abarcar um sem-número de eventos singulares de uma mesma natureza, os quais integram, por compartilharem propriedades invariantes expressas em seu conceito, um mesmo conjunto.

Sobre as propostas de definições teóricas e sintéticas do conceito de golpe de Estado, podem ser citadas duas recentes e salutares iniciativas. A primeira, de Álvaro Bianchi, tem o objetivo de demarcar as diferenças entre o conceito geral de golpe de Estado e a sua modalidade mais frequente, o golpe militar. Segundo o autor, essa proeminência em relação às outras possibilidades de golpe "fez com que muitas vezes o coup d'État fosse identificado exclusivamente com sua variante militar" (BIANCHI, 20I6). No sentido de, então, "considerar a hipótese de golpes promovidos por grupos do Poder Legislativo ou Judiciário ou por uma combinação de vários grupos e facções" (BIANCHI, 20I6), Bianchi propõe uma definição do conceito que deve indicar "o protagonista daquilo que se chama coup d'État, os meios que caracterizam a ação e os fins desejados" (BIANCHI, 20I6). Em sua nova forma,

o sujeito do golpe de Estado moderno é, como Luttwak destacou, uma fração da burocracia estatal. O golpe de Estado não é um golpe no Estado ou contra o Estado. Seu protagonista se encontra no interior do próprio Estado, podendo ser, inclusive, o próprio governante. Os meios são excepcionais, ou seja, não são característicos do funcionamento regular das instituições políticas. Tais meios se caracterizam pela excepcionalidade dos procedimentos e dos recursos mobilizados. O fim é a mudança institucional, uma alteração radical na distribuição de poder entre as instituições políticas, podendo ou não haver a troca dos governantes. Sinteticamente, golpe de Estado é uma mudança institucional promovida sob a direção de uma fração do aparelho 
de Estado que utiliza para tal medidas e recursos excepcionais que não fazem parte das regras usuais do jogo político (BIANCHI, 2016).

Sobre essa proposição de Bianchi, Martuscelli (2018) - que estabelece a segunda proposta de redefinição conceitual — destaca duas inconsistências. A primeira, de ordem interna, e a segunda, de ordem externa. O problema interno na proposição de Bianchi seria enunciar que o sujeito do golpe é sempre uma fração da burocracia estatal enquanto aventa a possibilidade de um golpe de Estado promovido pelo Poder Legislativo, que, sendo constituído por representantes políticos eleitos por tempo determinado, não integra a burocracia, constituída por funcionários permanentes e autonomeados. O problema de ordem externa, segundo Martuscelli, refere-se ao ocultamento no conceito de golpe de uma propriedade invariante do fenômeno. Qual seja, o vínculo necessário entre a dinâmica dos processos golpistas e os conflitos pela hegemonia no interior do bloco no poder. Seria ainda possível destacar um terceiro elemento de crítica que se insere na avaliação da proposta de Bianchi, que se refere à "alteração radical na distribuição de poder entre as instituições políticas" como resultado inexorável dos golpes. Um golpe cujo resultado é a substituição de um governante por outro sem alterar as funções institucionais dos cargos deixa, por isso, de ser um golpe?

Com o intuito de oferecer uma alternativa que supere os problemas indicados no conceito de Bianchi, Martuscelli propõe a seguinte definição:

Consideramos que todo golpe de classe [de Estado] $]^{5}$ possui uma direção política que está associada às disputas existentes no interior das classes dominantes pelo controle do processo decisório estatal, inscrevendo-se assim no rol de conflitos vinculados à própria lógica de reprodução social, em especial dos processos de redefinição ou reforço da hegemonia política de uma dada fração dominante no bloco no poder. Além disso, procuramos incorporar a tese já desenvolvida por outros analistas segundo a qual todo golpe é levado a cabo por iniciativa de agentes internos às instituições estatais, mas apontando para uma retificação importante de tais análises, ao demonstrar que tais agentes não estão alheios aos conflitos de classe. Por fim, caracterizamos o golpe de Estado como um ato de usurpação realizado por forças de oposição a um dado governo. Portanto, são esses três elementos: disputa pelo controle do processo decisório estatal, ação de agentes internos às instituições estatais e consumação de atos de usurpação contra um dado governo, que devem ser observados pelas análises de orientação marxista acerca dos golpes de Estado (MARTUSCELLI, 20I8, p. 13).

5 No texto original que referenciamos lê-se "golpe de classe", no entanto, intuímos pelo contexto da frase que se trata de um erro de redação, ante o qual o correto seria "golpe de Estado". 
O destaque que Martuscelli atribui aos conflitos entre frações no bloco no poder é importante no sentido de demarcar as diferenças de avaliação entre os analistas informados pela teoria marxista e os informados pelas assim chamadas teorias formalistas (liberais e elitistas). No entanto, a referência a tais conflitos no processo de formulação conceitual parece constituir uma redundância teórica, pois é um pressuposto da teoria marxista que os fenômenos políticos são animados pelos conflitos entre classes e frações. Portanto, não se trata de um atributo particular que especifica o golpe de Estado, mas de um atributo geral próprio a todos os fenômenos políticos e, como tal, um pressuposto que não precisa ser enunciado nos conceitos particulares.

O segundo aspecto que merece ser observado na proposta de Martuscelli é que, ao se referir à "ação de agentes internos às instituições estatais", o autor não observa a diferença entre os agentes do burocratismo e os agentes propriamente políticos. Considera-se, portanto, aqui, importante refinar o conceito de golpe em relação à teoria da organização do aparelho de Estado de tipo capitalista, o que constitui o objetivo principal deste ensaio. Entende-se, assim, que o aparelho de Estado capitalista é organizado sob uma hierarquia estrutural que lhe é própria e que precisa ser observada, ou seja, a primazia da representação burocrática sobre a representação política nas conjunturas de reprodução da dominância do modo de produção capitalista. A consideração dessa hierarquia entre os ramos do aparelho de Estado traz implicações para a possibilidade de caracterizar um golpe de Estado como golpe parlamentar puro, desconsiderando a presença e o papel político da burocracia nesses acontecimentos.

Tomando a teoria marxista do Estado como referência, observa-se que o golpe de Estado deve ser entendido como um tipo particular de prática política. Para que se avance no conhecimento desse tipo particular de prática política deve-se, então, partir dos conceitos de prática em geral e de prática política, especificamente. O conceito desse tipo particular de prática política deve, assim, conter os elementos do conceito geral e os elementos particulares que o especificam, diferenciando-o das demais modalidades de prática política e do próprio conceito de prática política em geral que o abarca.

Althusser, em Por Marx, define a prática em geral como "todo o processo de transformação de uma matéria-prima determinada em um produto determinado, transformação efetuada por um trabalho humano determinado, utilizando meios (de 'produção') determinados" (ALTHUSSER, 2015, p. 136). Partindo da definição de prática em geral, o filósofo franco-argelino designa a prática política do seguinte modo:

a prática política - que, nos partidos marxistas, já não é espontânea, mas organizada baseando-se na teoria científica do materialismo histórico, e que transforma sua matéria-prima, as relações sociais, em um produto determinado (novas relações sociais) (ALTHUSSER, 2015, p. 136).

A definição de prática em geral de Althusser é composta pela articulação de 
quatro elementos: um sujeito praticante, os meios mobilizados, uma matéria-prima e um produto. Sobre a sua definição específica de prática política, é possível observar que ela é incipiente, ou melhor, é inexistente do ponto de vista teórico geral. $\mathrm{O}$ excerto acima não oferece uma definição em geral de prática política, mas especifica já um tipo de prática política - a prática política revolucionária - sem antes definir a prática política em geral. É possível inferir, a partir da leitura, que os sujeitos praticantes o fazem organizados em partidos (marxistas ou não); que seus meios são espontâneos ou cientifica-

A burocracia praticante pode agir sozinha ou em aliança com a representação política. No primeiro caso temse ou um golpe militar ou um golpe judicial. No segundo caso, um golpe jurídicoparlamentar mente orientados; que sua matéria-prima são as relações sociais; e que seu produto é a transformação das relações sociais existentes.

Tomando um tipo específico de prática política para ilustrar o conceito geral de prática política sem defini-lo, Althusser toma características particulares da prática política revolucionária como características das práticas políticas em geral, que deveriam estar consubstanciadas no oposto das práticas políticas revolucionárias, as práticas políticas reiterativas (LAZAGNA, 2017). Ora, se as relações sociais são a matéria-prima de toda prática política e se toda prática política deve ter como produto novas relações sociais, as únicas práticas políticas dignas desse nome seriam as práticas políticas revolucionárias, sendo impossível categorizar práticas políticas destinadas à reprodução das relações sociais existentes.

Uma alternativa retificadora à proposta de Althusser é encontrada na obra Poder político e classes sociais, de Poulantzas, que diz:

trata-se, muito precisamente, da concepção indicada da prática política: esta tem por objeto o momento atual, ela produz as transformações — ou, aliás, a manutenção da unidade de uma formação, porém somente na medida exata em que tem como ponto de impacto, como objetivo estratégico específico, as estruturas políticas do Estado [...]. O que de fato se destaca nessa citação é que esse objetivo do poder de Estado é a condição da especificidade da prática política (POULANTZAS, 20I9, p. 44-45).

Poulantzas corrige a definição de Althusser, que limita as práticas políticas às de tipo revolucionário, especificando de modo mais preciso o objeto dessa prática e a orientação de seus efeitos. Se em Althusser o objeto aparece como "relações so- 
ciais existentes", em Poulantzas aparece, inspirado em Lênin, como o momento atual, entendido antes e depois como sinônimo de conjuntura. O segundo apontamento destina-se a especificar os efeitos dessas práticas específicas sobre essa matéria-prima específica, ou seja, os efeitos sobre o exercício de poder de Estado.

Tomando como parâmetro a definição de prática em geral e os apontamentos sobre a prática política, têm-se o seguinte: o sujeito da prática política é uma coletividade; os meios são os diversos métodos mobilizados e que precisariam ainda ser inventariados $^{6}$; a matéria-prima são os elementos da conjuntura; e os efeitos são as repercussões nas condições de exercício do poder de Estado. Sinteticamente, a prática política é o trabalho de uma coletividade que mobiliza meios específicos sobre uma conjuntura visando produzir repercussões nas condições de exercício do poder de Estado.

A variação desses quatro elementos, então, oferece uma definição de golpe como uma modalidade de prática política. Sinteticamente, golpe de Estado é a modalidade de prática política em que a burocracia participa da usurpação do exercício de poder $^{7}$ de um ou mais ramos do aparelho de Estado visando ao controle sobre o processo político. A prática política golpista então se caracteriza por um sujeito praticante específico, a burocracia de Estado; por um tipo de trabalho específico: a usurpação; por um tipo específico de matéria-prima: os ramos do aparelho de Estado; e por um objetivo: o controle do processo político.

\section{Quadro 1 - Definições de prática em geral, de prática política e de prática política golpista

\begin{tabular}{|c|c|c|c|c|}
\hline \multicolumn{5}{|c|}{ DEFINIÇÃO MAIS GERAL } \\
\hline PRÁTICA & $\begin{array}{l}\text { SUJEITO } \\
\text { PRATICANTE }\end{array}$ & $\begin{array}{l}\text { MEIO DE } \\
\text { PRODUÇÃO }\end{array}$ & MATÉRIA-PRIMA & PRODUTO \\
\hline PRÁTICA POLÍTICA & COLETIVIDADE & $\begin{array}{l}\text { DIFERENTES } \\
\text { MÉTODOS DE } \\
\text { INTERVENÇĀO }\end{array}$ & $\begin{array}{l}\text { ELEMENTOSDA } \\
\text { CONJUNTURA }\end{array}$ & $\begin{array}{l}\text { EFEITOS SOBRE AS } \\
\text { CONDIÇÕES DE } \\
\text { EXERCÍCIO DO PODER } \\
\text { DE ESTADO }\end{array}$ \\
\hline $\begin{array}{l}\text { PRÁTICA POLÍTICA } \\
\text { GOLPISTA }\end{array}$ & BUROCRACIA & USURPAÇÃ̃O & $\begin{array}{l}\text { RAMOS DO } \\
\text { APARELHO DE } \\
\text { ESTADO }\end{array}$ & $\begin{array}{l}\text { EFEITOS SOBRE O } \\
\text { CONTROLE DO } \\
\text { PROCESSO POLÍTICO }\end{array}$ \\
\hline \multicolumn{5}{|c|}{ DEFINIÇÃO MAIS PARTICULAR } \\
\hline
\end{tabular}

Fonte: elaboração própria.

Tomando essa definição, propõe-se aqui o exercício de combinar variações nos quatro elementos especificados da prática golpista. Adverte-se, no entanto, que não se pretende combinar todas as possibilidades teóricas indicando também as suas

6 Exemplos: eleição de representantes, acordo parlamentar, protesto de massa, greve geral, guerra popular etc.

7 Frisa-se aqui o termo exercício do poder, pois o poder político é sempre o poder de uma classe social, transitando de uma classe para outra somente em condições muito específicas. 


\section{O golpe jurídico-parlamentar}

tem como sujeitos praticantes

a burocracia civil judiciária e o

parlamento a ela aliado, os quais

usurpam o exercício do poder político por meios institucionais. Sua matériaprima é sempre a cabeça de governo e o processo político é controlado sem modificar a forma de Estado, deteriorando o regime democrático vigente, podendo alterá-lo ou não

impossibilidades. Essa demanda legítima e necessária poderá ser desenvolvida em outra oportunidade. $\mathrm{O}$ que interessa aqui é indicar a capacidade produtiva do conceito. Observe-se, então, mais de perto, quais são as suas combinações.

A burocracia praticante pode agir sozinha ou em aliança com a representação política. No primeiro caso tem-se ou um golpe militar ou um golpe judicial. No segundo caso, um golpe jurídico-parlamentar. A variação no meio de produção diz respeito à forma da usurpação. Essa usurpação pode ser institucional (pela manipulação das regras proclamadas) ou anti-institucional (pela quebra das regras proclamadas). A matéria-prima varia de acordo com o ramo do aparelho de Estado, a cabeça do governo, o parlamento ou o Judiciário. O controle do processo político pode se dar pela alteração da forma de Estado e, consequentemente, do regime político, ou pela alteração/deterioração do regime político sem a alteração da forma de Estado.

Destacados os elementos para o exercício teórico de sua combinação, considerar-se-á, para os fins deste exercício, apenas a possibilidade de golpes em regimes políticos democráticos. A também legítima e necessária indicação de impossibilidades e possibilidades de outras combinações teóricas reserva-se para outro momento.

Em regimes democráticos, o golpe de tipo militar tem a seguinte configuração. A coletividade praticante é a burocracia militar, a usurpação é de tipo anti-institucional, a matéria-prima é composta por dois ou três ramos do aparelho de Estado (parlamento e Judiciário ou parlamento, Judiciário e cabeça do governo) e o controle do processo político dá-se pela alteração da forma de Estado democrática para a forma ditatorial sob o regime de ditadura militar. 
No golpe de tipo judicial, a coletividade que se impõe é a burocracia civil, a usurpação é sempre anti-institucional, a matéria-prima são um ou dois ramos do aparelho de Estado (parlamento ou parlamento e cabeça do governo) e o controle do processo político se dá pela alteração da forma de Estado democrática para a forma ditatorial sob o regime da ditadura bonapartista.

O golpe jurídico-parlamentar tem como sujeitos praticantes a burocracia civil judiciária e o parlamento a ela aliado, os quais usurpam o exercício do poder político por meios institucionais ${ }^{8}$. Sua matéria-prima é sempre a cabeça de governo e o processo político é controlado sem modificar a forma de Estado, deteriorando o regime democrático vigente, podendo alterá-lo ou não (em caso de alteração, do presidencialismo para o parlamentarismo).

\section{Quadro 2 - Modalidades de golpe segundo a variação dos seus elementos constitutivos}

\begin{tabular}{|c|c|c|c|c|}
\hline \multicolumn{5}{|c|}{ VARIAÇŌES QUE ESPECIFICAM MODAUIDADES DE GOLPE EM REGIMES DEMOCRÁTICOS } \\
\hline TIPO DE GOLPE & $\begin{array}{l}\text { RAMO PRATICANTE DA } \\
\text { BUROCRACIA }\end{array}$ & TIPO DE USURPAÇ̄̃OO & RAMOS DE MATERIA-PRIMA & $\begin{array}{l}\text { TIPOS DE EFEITOS SOERE } \\
\text { CONTROLE DO PROCESSO } \\
\text { POLIIICO }\end{array}$ \\
\hline GOLPE MILITAR & MILITAR & ANTI-INTITUCIONAL & $\begin{array}{l}\text { (JUDICIÁRIO + PARLAMENTO) } \\
\text { OU (JUDICIÁRIO + } \\
\text { PARLAMENTO + CHEFE DO } \\
\text { GOVERNO) }\end{array}$ & $\begin{array}{l}\text { ALTERAÇÃO DA FORMA DE } \\
\text { ESTADO DE DEMOCRACIA } \\
\text { PARA DITADURA SOBO } \\
\text { REGIME MIUTAR }\end{array}$ \\
\hline GOLPE JUDICIAL & COVIL & ANTI-INTITUCIONAL & $\begin{array}{l}\text { (PARLAMENTO) OU } \\
\text { (PARLAMENTO + CHEFE DO } \\
\text { GOVERNO) }\end{array}$ & $\begin{array}{l}\text { ALTERAÇÃO DA FORMA DE } \\
\text { ESTADO DE DEMOCRACIA } \\
\text { PARA DITADURA SOBO } \\
\text { REGIME BONAPARTISTA }\end{array}$ \\
\hline $\begin{array}{l}\text { GOLPE JURÍDICO- } \\
\text { PAALAMENTAR }\end{array}$ & CIVIL + PARLAMENTO & INSTITUCIONAL & CHEFE DO GOVERNO & $\begin{array}{l}\text { NAOO ALTERA A FORMA DE } \\
\text { ESTADO, ALTERA OU } \\
\text { DETERIORA O REGIME } \\
\text { POLÍIICO DEMOCRÁnICO }\end{array}$ \\
\hline
\end{tabular}

Fonte: elaboração própria.

Nos dois primeiros tipos de golpe, o efeito imediato é o estabelecimento de um regime hegemonizado ou pela burocracia militar ou pela burocracia civil, que conformam, respectivamente, as ditaduras militares e as ditaduras bonapartistas. No golpe de terceiro tipo, a crise política tende a se prolongar com o desgaste progressivo das instituições, sem que imediatamente um ramo do aparelho se imponha como dominante, prolongando e agravando a crise institucional.

O golpe de tipo jurídico-parlamentar abre um limbo no qual nenhum ramo do aparelho de Estado é forte o suficiente para redesenhar e estabilizar uma nova hierarquia institucional duradoura. Os ramos do aparelho de Estado adquirem maior autonomia entre si, digladiando-se num conflito sem resolução, sempre ampliando as margens de exercício de suas prerrogativas pela ampliação das fronteiras de suas 
atribuições. Nesse ponto, a única certeza possível é de que as coisas não permanecerão como estão. É possível haver restauração da força das instituições democráticas? Sim. É possível haver um segundo golpe, de caráter anti-institucional, que estabeleça a supremacia de um dos ramos sobre os outros, alterando a forma de Estado da democracia para a ditadura? Também.

É interessante notar que é na deterioração da forma democrática sem sua imediata substituição pela forma ditatorial que podem emergir alguns dos elementos constitutivos do tipo de crise que aduba o fascismo, tais como: o acirramento de conflitos e a incapacidade hegemônica no bloco no poder; a crise de representação dos partidos burgueses; o ativismo da burocracia e a crise institucional; e a "constituição da pequena burguesia como força social distinta" (BOITO JR., 202Ib).

Aqui não se pretende afirmar que o tipo de crise política que aduba o fascismo só pode ser produzido por um golpe jurídico-parlamentar, mas que essa crise política é a crise de uma democracia deteriorada e que essa condição do regime democrático se produz também por golpes jurídico-parlamentares. Um golpe que imediatamente instala um regime ditatorial tende, de uma só vez, a resolver o acirramento dos conflitos e a incapacidade hegemônica no bloco no poder, a crise dos partidos burgueses e a instabilidade institucional permanente, além de inviabilizar a constituição da pequena burguesia como força social distinta, organizada em movimento de massa.

Sobre este último elemento, a constituição da pequena burguesia em força social distinta, a democracia deteriorada cumpre um papel fundamental. Nesse cenário é que a "ideologia superficialmente crítica" do fascismo tem espaço para ecoar e ter penetração de massa. É nesse cenário que o movimento de massa pode emergir e se constituir enquanto partido policial e ser absorvido passivamente pelos ramos de um aparelho em crise sedento por estabilidade, convertendo-se em ramo do aparelho. Trata-se da polícia política que, inadmitindo secessões, restabelece uma nova ordem, mesmo que precária. Absorvida pelo aparelho e tornando-se ramo dominante, a polícia política é o elemento que transforma o governo fascista num tipo particular de regime. Em referência à obra de Poulantzas Fascismo e ditadura, Danilo Martuscelli destaca que "com a consolidação do regime fascista, é a polícia política que se torna o ramo dominante e passa a deter o controle sobre o processo decisório estatal" (MARTUSCELLI, 202I, p. 56).

Esse breve desvio feito sobre as consequências da crise instalada por um golpe jurídico-parlamentar serve para "alertar" sobre uma primeira impressão possível, de que esse tipo de golpe é mais brando ou tem consequências menos graves para a reprodução da forma de Estado democrática. Trata-se, na verdade, de um golpe com consequências gravíssimas para a reprodução de regimes de tipo democrático e cujos desfechos, porém, não são imediatos e certeiros como os dos golpes militares ou judiciais.

Desta última seção do desenvolvimento, o mais importante a destacar é a definição de golpe de Estado como uma prática política típica da burocracia, que, 


\section{O mais importante a} destacar é a definição de golpe de Estado como

\section{uma prática política} típica da burocracia, que, agindo sozinha

ou em conluio com os

representantes políticos,

usurpa o exercício de

poder de ramos do

aparelho de Estado

agindo sozinha ou em conluio com os representantes políticos, usurpa o exercício de poder de ramos do aparelho de Estado. Essa definição, integrando o conceito de golpe de Estado à teoria marxista do Estado, tem como consequência principal a interdição do golpe parlamentar como uma caracterização possível.

\section{CONSIDERAÇ̃̃ES FINAIS}

O itinerário argumentativo do presente ensaio partiu da constatação de uma incongruência entre um postulado da teoria marxista do Estado e um diagnóstico analítico sobre um suposto tipo de golpe de Estado. Enquanto o referido postulado assevera o primado da representação burocrática sobre a representação política nas conjunturas de reprodução, o diagnóstico analítico atesta a existência de golpes parlamentares.

Considerando o embasamento analítico de argumentos que sustentam a caracterização do golpe do impeachment de 2016 como golpe parlamentar, foi possível observar a presença constante e fundamental da burocracia de Estado. Essa presença, no entanto, é ocultada das caracterizações que advogam a tese do golpe parlamentar, porque elas consideram a primazia das forças perpetradoras sobre as forças que criam as condições, do ponto de chegada sobre o processo ou da superfície do rito institucional na cena política sobre a presença interessada e dissimulada da burocracia.

A mobilização da teoria marxista do Estado burguês permitiu localizar o fenômeno do golpe de Estado como uma prática política típica da burocracia. Como 
prática política de tipo particular, foi possível identificar os elementos da prática política em geral que constituem as variações que especificam a prática política golpista. O exercício de combinações possíveis em um cenário específico possibilitou vislumbrar, sem esgotá-las, algumas das modalidades de prática política golpista possíveis, bem como os seus efeitos mais prováveis.

Como exercício final de ilustração da operacionalidade do conceito sob essa nova forma, pode-se aplicá-lo ao golpe do impeachment de 20I6, acontecimento abordado lateralmente na segunda seção. O caráter golpista daquele evento se definiu pela participação da burocracia jurídica como um dos sujeitos praticantes, afinal nem todo impeachment pode ser caracterizado como golpe. $\mathrm{O}$ meio de usurpação do exercício do poder, o impeachment, deu-se pela participação - autorizada e legitimada pela burocracia jurídica - do parlamento, o outro sujeito praticante. Trata-se, portanto, de uma usurpação institucional, na medida em que as leis e os ritos são mobilizados e reafirmados pela prática e pelo discurso golpista. $\mathrm{O}$ resultado das práticas institucionais de usurpação pelo parlamento e pelo Judiciário sobre a chefe do governo não foi uma alteração da forma de Estado, mas uma deterioração do regime democrático. $\mathrm{O}$ ponto de chegada da análise é de que o golpe do impeachment de 2016 foi um golpe jurídico-parlamentar.

Como última advertência sobre as pretensões deste texto, destaca-se a indicação do seu caráter ensaístico. A proposta, aqui, é a de dar um tratamento teórico a um termo de uso corrente mobilizado pelos analistas marxistas para a observação de um fenômeno cujo conceito não tem ainda na teoria marxista uma formulação estrita e rigorosa. Sem a presunção de superar o problema, apresentou-se aqui um caminho possível que parece ser, num primeiro momento, do ponto de vista teórico, coerente, e, do ponto de vista analítico, fecundo: o golpe de Estado como prática política típica da burocracia.

\section{* Doutorando em Ciência Política na Universidade Estadual de Campinas (Unicamp).}

Agradeço ao professor Danilo Enrico Martuscelli pela sua generosidade intelectual ao considerar minhas inquietações sobre o conceito de golpe de Estado, debatendo a questão, entre convergências e divergências, sempre de modo honesto e rigoroso.

Texto recebido 5 agosto de 2021; aprovado em $1^{\circ}$ de novembro de 2021. 
ALTHUSSER, Louis. Por Marx. Campinas: Editora da Unicamp, 2015.

BIANCHI, Álvaro. O que é um golpe de Estado? Blog Junho, mar. 2016. Disponível em: <https://docero.com.br/doc/exxvnxn>. Acesso em: 8 nov. 2021.

BOITO JR., Armando. Dilma, Temer e Bolsonaro: crise, ruptura e tendências na política brasileira. Goiânia: Phillos Academy, 2020.

Duas concepções de política em Marx: os escritos juvenis e a obra da maturidade. [S.I.]: Rondó da Liberdade, 18 jan. 2021a. 78 min. Disponível em: <www.youtube.com/watch?v=C-tZwaB7hSU\&list=PL3SagG8Tcnls57L85QtdGsIVQze0xsUso\&ab_channel=Rond\%C3\%B3daLiberdade>. Acesso em: 1 nov. 2021.

O caminho brasileiro para o fascismo. Caderno CRH, Salvador, v. 34, p. 1-23, 2021 b.

CONCEITO. In: DICIONÁRIO Michaelis. São Paulo: Melhoramentos, 2021. Disponível em: <https:// michaelis.uol.com.br/moderno-portugues/busca/portugues-brasileiro/conceito>. Acesso em: 1 nov. 2021.

LAZAGNA, Ângela. O político na transição socialista: explicação e retificação da contribuição da corrente althusseriana. 2017. Tese (Doutorado) — Instituto de Filosofia e Ciências Humanas, Universidade Estadual de Campinas, Campinas, 2017.

MARTUSCELLI, Danilo Enrico. Nicos Poulantzas e a teoria política do fascismo: 50 anos depois. Princípios, n. 161, p. 42-60, mar.-jun. 2021. Disponível em: <https://doi.org/10.4322/principios.2675-6609.2021.161.003>. Acesso em: 1 nov. 2021.

golpe de Estado como fenômeno indissociável dos conflitos de classe. Demarcaciones, $\mathrm{n}$. 6, p. 1-15, 2018.

PERISSINOTTO, Renato. Por que golpe?. Mímeo, 2016. Disponível em: <www.academia. edu/29221192/Por_que_golpe>. Acesso em: 1 nov. 2021.

POULANTZAS, Nicos. Poder político e classes sociais. Campinas: Editora da Unicamp, 2019.

SAES, Décio. A formação do Estado burguês no Brasil (1889 -1891). 1982. Tese (Livre-docência) — Instituto de Filosofia e Ciências Humanas, Universidade Estadual de Campinas, Campinas, 1982.

A república do capital: capitalismo e processo político no Brasil. São Paulo: Boitempo, 2001.

Democracia. São Paulo: Ática, 1987.

O lugar dos conceitos de estrutura e instituição na pesquisa em educação. Cadernos Ceru, v. 23, n. 1, p. 281-296, 2012.

SINGER, André. Lulismo em crise: um quebra-cabeça do período Dilma (2011-2016). São Paulo: Companhia das Letras, 2018.

SOUZA, Jessé. A radiografia do golpe: entenda como e por que você foi enganado. Rio de Janeiro: Leya, 2016. 